\title{
A LITHOSTRATIGRAPHIC ANALYSIS OF THE CROOKED RIVER MASCALL FORMATION, CENTRAL OREGON, USA
}

by

ALEXANDRA ELISE THOMPSON

\begin{abstract}
A THESIS
Presented to the Department of Earth Science and the Robert D. Clark Honors College in partial fulfillment of the requirements for the degree of Bachelor of Science
\end{abstract}

May 2020 


\title{
An Abstract of the Thesis of
}

Alexandra Thompson for the degree of Bachelor of Science in the Department of Earth Science to be taken May 2020.

Title: A Lithostratigraphic Analysis of the Crooked River Mascall Formation, Central Oregon, USA

\author{
Approved: _ Samantha S.B. Hopkins, PhD \\ Primary Thesis Advisor
}

This project presents a comprehensive lithostratigraphic record of the Middle Miocene Mascall Formation deposits of the Crooked River Basin in Central Oregon, USA. The Columbia River Basalt Group (CRBG) covered the Crooked River Basin and much of the Pacific Northwest in the middle Miocene (17-13ma), altering the landscape and ecosystem. An analysis of the depositional history of this region in the aftermath of the CRBG eruptions allows us to explore the impact of large scale basalt flows on subsequent basin evolution in a region that lacks extensive lithostratigraphic data. University of Oregon field crews have measured stratigraphic sections in several different locations across the Crooked River basin in order to quantify the differences in depositional history across the basin and reconcile stratigraphy across multiple field expeditions. The regions we have defined for a holistic representation of the region are Twin Buttes in the northwest, Cave Basin in the northeast, Hawk Rim in the southwest, South Fork of the Crooked River - West in the southwest, and South Fork of the Crooked River - East in the southeast. They are situated between the lower boundary CRBG and upper capping Rattlesnake Ash Flow Tuff (RAFT). For each region, we have created a representative stratigraphic column, and we correlate the depositional 
units between these disparate areas. The Mascall Formation in the Crooked River Basin is consistent with published descriptions of the Lower Mascall Formation: mostly fine siltstone and sandstone with diatomite, ash, and chert deposits and some tuff strata (Bestland, 1998). Each of the four sites share characteristics of the Lower Mascall which suggests similar depositional environments across the sites; however, the sections vary in the thickness and representation of individual identifiable strata, suggesting variation in Mascall deposition. This project presents a refined description of the Crooked River Mascall Formation and is the first comprehensive assessment of the stratigraphy of the Crooked River Basin, which will have significant implications for understanding landscape reorganization following large-scale basaltic volcanism as well as clarifying stratigraphic relationships between the Crooked River Mascall and the type-area Mascall Formation. 


\section{Acknowledgements}

I would like to thank Professor Samantha Hopkins for assisting me in the completion of my undergraduate thesis. Thank you to Professor Ray Weldon and Larry Syu-Heng Lai for serving as members of my thesis committee. It has been a great privilege to have the opportunity to work with many amazing mentors in the field and in the lab. I appreciate the support, patience, and encouragement I received from all members of the committee. My love for geology is inspired by my mentors’ passions.

I would like to thank all the University of Oregon geology students who measured stratigraphic columns in the Crooked River Basin over the past ten field seasons. This project would not be possible without their valuable data collection and field notes. I would like to specifically thank the UO Geology Field Campers of the summer of 2019 for making six weeks in the field bearable and fun. Thank you to the University of Oregon department of Earth Science for preparing me fully for the research involved in the completion of this project. I am grateful for the professors and graduate teaching fellows who taught me how to read the rocks and think like a geologist.

I would like to thank my parents for supporting my undergraduate education at the Robert D. Clark Honors College. It has been a challenging journey in many ways, but will be a dream come true to graduate from this institution. I would like to thank Katie Thompson, Megan Wyatt, Jordan Pickrel, and John Biemann for their love and support along my journey to the completion of this project.

Table of Content 


$\begin{array}{lr}\text { Introduction } & 1 \\ \text { The Type-Area John Day Mascall Formation } & 1 \\ \text { The Study Area: The Crooked River Mascall Formation } & 2 \\ \text { Climate Change } & 4 \\ \text { Columbia River Basalt Group } & 5 \\ \text { METHODS } & 6 \\ \text { Field Sites } & 6 \\ \text { Measuring Stratigraphic Columns } & 6 \\ \text { Correlation of Stratigraphic Columns } & 8 \\ \text { RESULTS } & 9 \\ \text { DISCUSSION } & 15 \\ \text { Description of the Crooked River Mascall } & 15 \\ \text { Paleo-Depositional Environments } & 15 \\ \text { Correlation Hypotheses } & 18 \\ \text { Further Directions } & 21 \\ \text { CONCLUSION } & 23 \\ \text { Figures } & 24 \\ \text { Bibliography } & 40\end{array}$




\section{List of Figures}

Figure 1: Map of Oregon with Salem, John Day, and the Study Area

Figure 2: Map of the Study Area

Figure 3: Simplified Stratigraphy of the john Day Sequence

Figure 4: Cave Basin Unit Descriptions

Figure 5: Cave Basin Stratigraphic Column

Figure 6: Twin Buttes Unit Descriptions

Figure 7: Twin Buttes Stratigraphic Column

Figure 8: Hawk Rim Unit Descriptions

Figure 9: Hawk Rim Stratigraphic Column

Figure 10: South Fork of the Crooked River - West Unit Descriptions

Figure 11: South Fork of the Crooked River - West Stratigraphic Column

Figure 12: South Fork of the Crooked River - East Unit Descriptions

Figure 13: South Fork of the Crooked River - East Stratigraphic Column

Figure 14: Fence Diagram Hypothesis One: The Unknown Tuff is the Hawk Rim Tuff

Figure 15: Fence Diagram Hypothesis Two: The Unknown Tuff is a New Tuff 


\section{Introduction}

\section{The Type-Area John Day Mascall Formation}

Geologists have explored and researched central and eastern Oregon extensively, with efforts dating back to the early 1900s. Paleontological exploration has been centered around the John Day Basin, which is a beautiful region about five hours by car away from Eugene, Oregon that is known for "painted” paleosols and a rich fossil record that encompasses 40 million years (Figure 1). Part of the John Day sedimentary sequence, the Mascall Formation, covers a span of time in the midMiocene, 16-13 million years ago, which records a changing climate and corresponding expansion of fauna in the region (Bestland, et al, 2008). Fossils found in the John Day Basin have shaped scientists' understanding of ancient Oregon's ecosystems and the organisms that lived here millions of years ago. Equally important to an understanding of paleontology is an understanding of the sedimentary units where fossils are found, and the volcanic units that constrain known geologic time.

Most of the literature about the Mascall has come out of the John Day Basin Mascall. Defining literature of the Mascall are descriptions of the Mascall fauna and a stratigraphic analysis of John Day prepared for the Bureau of Land Management (BLM) and National Monument. In addition to the literature that exists about the fauna and stratigraphy of the area, it is helpful to familiarize with the ecological changes that were occurring during the mid-Miocene with the context of climate change and reorganization of faunal diversity. Looking at the Mascall, specifically, may be helpful for piecing together information about climate change and faunal diversity because it was deposited during the mid-Miocene. The mid-Miocene is a time of the landscape 
change, namely the introduction and the spread of grasslands and open wooded areas, which led to the diversification of equids (Retallack, 2004).

\section{The Study Area: The Crooked River Mascall Formation}

Concerning the literature specifically about the Crooked River Mascall, there are fewer published papers in this area. McLaughlin (2016) is the only published work that focuses specifically on Crooked River assemblages, and contains most valuable information about the Crooked River Mascall specifically. Hawk Rim is one of the most thoroughly studied localities in the Crooked River Mascall, and descriptions of the lithology of the Mascall at Hawk Rim helps to characterize the differences between the Crooked River Mascall and the John Day type-area Mascall (Figure 2). The focus of the paper is more deeply on the new vertebrate fauna that was discovered at Hawk Rim, but an in-depth lithostratigraphic context section and geochronology section put a characteristic description of the Mascall and the more accurate proposed age of the formation into the literature.

The Crooked River Basin is located south of the John Day Basin, separated by the Ochoco Mountains (Figure 1). The entire tertiary John Day section is found in the Crooked River Basin, with one tie between the John Day Basin and the Crooked River Basin being the Mascall Formation (Figure 3). The Mascall is a tan-brown, silty, clayey, alluvial floodplain deposit that is situated stratigraphically between volcanic tuffs. The Columbia River Basalt Group (CRBG) is a flood basalt whose source is attributed to the Yellowstone plume. It is the youngest continental flood basalt, and was deposited in the Pacific Northwest of North America. Due to the size and multiple eruptive events, the CRBG has been divided into subgroups. The subgroup of the CRBG that is situated 
below the Mascall Formation is called the Picture Gorge Basalt (PGB) and is dated between 17.23 $\pm 0.04 \mathrm{Ma}$ and 16.06 $\pm 0.14 \mathrm{Ma}$ (Cahoon, 2020). The Rattlesnake Ash Flow Tuff (RAFT) is situated stratigraphically above the Mascall, and has been radiometrically dated to be $7.05 \pm 0.01 \mathrm{Ma}$ (Streck, 1999). The Mascall lies in between these two volcanic deposits, so the age of the Mascall is between 17.23 Ma and 7.05 Ma. It has been mapped around portions of central Oregon and is distinguishable in part due to its light tan to yellowish appearance that tends to weather out of hillslopes and can be visible in aerial photographs.

The type-area Mascall Formation, found in the John Day Basin, has been observed and researched fairly extensively and is often divided into two sections: the Upper Mascall Formation and the Lower Mascall Formation due to the differences in lithology of the areas (Bestland, 1998). The Upper Mascall Formation is characterized by higher clay and conglomerate content while the Lower Mascall Formation has more siltstone and unique diatomite deposits (McLaughlin, et. al, 2016). The Crooked River Basin's exposures of the Mascall Formation have been studied less extensively, with the primary focus of published research coming from the Hawk Rim locality. Research at Hawk Rim established that the Crooked River Mascall there generally matches the characteristics described for the type-area Lower Mascall Formation more closely, due to almost entirely siltstone deposits with very little clay (McLaughlin, et. al, 2016). Other sites in Crooked River are also characteristic of the lower Mascall formation. Some sediments in Crooked River are characteristic of the upper Mascall, but none of those characteristics were exposed in the five field sites evaluated in this study. 
This project is an effort to describe the Crooked River Mascall in greater specificity and provide a hypothesis for its deposition across the Crooked River Basin. Sedimentology, stratigraphy, paleontology, and basin analysis have been used to study the area, with the goal of highlighting key characteristics of the Mascall, how it was deposited across the basin, and how carefully chosen field sites' stratigraphic columns connect with one another laterally across inaccessible land. The deeper understanding that this project provides is a valuable tool for placing fossils discovered in the area into a wider stratigraphic context, in terms of climate, topography, and geologic time.

\section{Climate Change}

The Mascall Formation is important to a deeper understanding of global climate change. The Middle Miocene Climatic Optimum occurred at the same time as the Mascall's deposition; therefore the Mascall records the changes that environments in Central Oregon underwent at that time. The landscape warmed and became more conducive to grasslands, and, in the Pacific Northwest, open woodlands (Cross and Taggart, 1982; Retallack, 2004). As grasslands began to spread and become more common in the landscape, an increase in faunal diversity came along with those changes (Behrensmeyer, 1992). This climate change and faunal diversity is captured in the paleontology of the Crooked River Mascall Formation. This study is not focused on a full paleontological analysis of the region, but we have been compiling fossil records from the Crooked River Basin for the past 10 years and stratigraphic columns presented here indicate specifically fossiliferous sections of the Mascall (Figures 5, 7, 9, 11, 13). An interesting and worthwhile area of research would be the comparison of the fauna from the Crooked River Mascall to the John Day Mascall. 


\section{Columbia River Basalt Group}

The Crooked River Basin is an important area of research because it serves as a model for an environment that was shaped by large-scale volcanism. The CRBG serves as a model for large-scale flood basalt volcanism because it is the youngest continental basalt province and it covers $>210,000 \mathrm{~km}^{3}$ (Cahoon, 2020; Reidel et al., 2013). The CRBG has been split into several provinces, including the Grand Ronde Basalt, which is the subgroup that the Picture Gorge Basalt (PGB) is a part of (Barry, et al., 2004). The deposition of the CRBG, specifically the PGB, underlie the Mascall formation and the study of this area will lead to a deeper understanding of the impacts of extensive basalt flows on the environment of the time. The PGB originated from the Monument dike swarm in northeastern Oregon and flowed south before the main-phase eruption of the CRBG as a whole (Fruchter and Baldwin, 1975; Reidel et al., 2013). The dike swarm that is associated with the PGB extends south to reach the study area. The involvement of the PGB with the landscape of Crooked River is important to acknowledge because an event of basaltic flooding has an impact on subsequent deposition within the basin. 


\section{METHODS}

\section{Field Sites}

Before any stratigraphic columns were used in this project, five field sites were chosen to provide a view of the Crooked River Basin. The sites cover part of the Crooked River Basin, enough to make inferences about deposition in the region, but not the entire basin. These sites are relatively close together, but cover all corners of the study area (Figure 2). All of the sites are chosen for the quality of exposure of the Mascall. Hawk Rim, located in the northwest, is a useful field site because the exposure of the HRT is remarkably clear, with a thickness of 5 meters exposed, as well as the main section of Hawk Rim being fossiliferous. Cave Basin, located in the northeast, is important because it is a thick section of well-exposed Mascall that is relatively fossiliferous. Twin Buttes, located in the northwest, is important because it shows the contact of the CRBG with the Mascall Formation. South Fork East and West are located in the southeast corner of the basin and are important because they provide insight into stratigraphy across on the East and West sides of the Crooked River. The reason two sites were chosen so close together is because the beds' dips on the East and West sides of the ravine expose different parts of the section.

\section{Measuring Stratigraphic Columns}

My primary method of analyzing the region is the creation and interpretation of measured stratigraphic columns. A stratigraphic column gives a simplified layout of the sorts of rocks that are situated in relation to one another at any given place. The goal is 
to accumulate enough accurate stratigraphic columns to draw conclusions about areas of the Crooked River Basin that are covered and not easily accessible, and further, to draw conclusions about the entire Crooked River Basin. A combination of stratigraphic columns measured in five different field sites around the Crooked River Basin have been connected laterally to draw conclusions about the covered regions.

I am relying largely upon data that has been collected by UO Earth Science field camp students and students affiliated with the Hopkins-Davis lab over the past 10 years. Five field sites have been defined and revisited over the years of study in the basin: Twin Buttes, Cave Basin, South Fork of the Crooked River East and West, and, most extensively, Hawk Rim. To organize where columns have been measured and can be measured in future studies, I used a combination of satellite photos from Google Maps and Google Earth with flagged waypoints that came from GPS devices used in the field (Figure 2).

In the field, stratigraphic columns of the Crooked River Mascall formation have been measured anywhere there is exposed rock. Strike and dip were taken using a Brunton compass, and that information was used to measure a decimeter-scale section with a Jacob’s staff and Abney level were used to measure the thickness of rock units by hand at all of the field sites. Based on what we measured at the field sites, the beds are relatively close to horizontal, with angles of dip around 1-8 degrees from horizontal. Using principles of sedimentology, in-depth unit descriptions were recorded in the field for any observable change in strata. Over several field seasons, stratigraphic columns have been measured by hand and described in detail. We studied the stratigraphic columns and field notes of the people who measured them and cross-referenced with 
columns that had been measured in the same location spanning different years. A representative stratigraphic column that detailed all marker beds and sedimentary structures was created for each of the five field sites, and those representative columns were taken into the field during the summer of 2019. With the representative columns that had been measured, re-measured, and described in detail over the years, we revisited every field site and verified the descriptions at each site. This ensured the accuracy and detail of descriptions. Additionally, with the same crew looking at each rock unit, descriptions could be streamlined and verified.

\section{Correlation of Stratigraphic Columns}

As described in the introduction, the Mascall Formation is bounded by a basalt flow, the Columbia River Basalt Group (CRBG) on the lower limit of the Mascall, and ash flow tuffs, the Rattlesnake Ash Flow Tuff (RAFT) and Divine Canyon Ash Flow Tuff (DAFT), on the upper limit. There are other dated tuffs in the region, including the Hawk Rim Tuff (HRT) and Double Tuff (McLaughlin, 2012). The identification and description of these dated tuffs have been used to correlate stratigraphic columns to one another, creating several fence diagrams that could represent the relationships between the five field sites in the basin. In addition to the dated tuffs and basalt present in the study area, there are other marker beds that can be used to correlate columns in the basin. Both Hawk Rim and Twin Buttes field sites contained diatomite and chert beds that can be correlated (Figures 7 and 9). Additionally, there are two field sites, Hawk Rim and South Fork East have sandstone beds that can be correlated (Figures 9 and 13). 


\section{RESULTS}

Across the five field sites, there are several correlateable ash flow tuffs, and similar depositional settings evidenced by the sites' comparative geologies. In Cave Basin, we identified the HRT and the RAFT, with a thick siltstone deposit between the two tuffs. In Hawk Rim, the correlateable units we identified are Double Tuff, the HRT, and the RAFT; other interesting units that were useful for analysis of the depositional environment of Hawk Rim are a chert deposit and a coarse sandstone. At Twin Buttes, we see the CRBs exposed, the HRT, and the RAFT. Like Hawk Rim, Twin Buttes also has a thick chert deposit in the lower section of stratigraphy. South Fork of the Crooked River West is a poorly exposed section, with much of it covered by thick soil. There are several tuffaceous siltstone units at South Fork West, but the primary correlateable tuff is the DAFT. At the South Fork of the Crooked River East, we identified the DAFT capped by the Tertiary Olivine Basalt (TOB). South Fork East is the only site where the TOB has been identified. There is another tuff we found at South Fork East, but a full chemical analysis to confirm the identity of the tuff has not yet been completed. Other notable units of South Fork East are a cross-bedded conglomerate and a coarse sandstone.

Based on the measured columns, I constructed three possible fence diagrams for correlation between the field sites (Figures 14 and 15). Because we cannot confirm definitely the identity of a tuff in South Fork East, several hypotheses for correlation have been proposed to account for that. The unknown tuff is about $2 \mathrm{~m}$ thick, resistant grey ashy bed; up to $20 \%$ pumice in cm sized pieces; shares a direct contact with the underlying cross bedded sandstone unit and a direct contact with the overlying covered 
interval. Based on this description of the unknown tuff, it seems to most closely match the identity of the HRT, which is also deposited in the area. In the first hypothesis, I suggest that the unknown tuff in South Fork East is a confirmed match with the HRT. This is a plausible suggestion based on the thickness of the unknown tuff and where it lies in the overall thickness of the column. The second hypothesis is that the unknown tuff in South Fork East does not match with any of the identified tuffs in the region. This is a less likely scenario because the description of the unknown tuff seems to either match the HRT, but it should be accounted for as a possibility. If the unknown tuff is actually a new tuff altogether, given that it is not described in any other field site, it would mean that the depositional range of the tuff would be incredibly localized, which makes this hypothesis unlikely to be the answer to the question of the unknown tuff's identity. It seems that the unknown tuff would at least be traceable in the closest site to South Fork East, which is South Fork West. Besides the possibility of correlating the stratigraphic columns, this project provides in-depth descriptions of the lithology of the five field sites. Figures 5-13 include stratigraphic columns and unit descriptions for each site.

Beginning in Hawk Rim, the westernmost site, the majority of the Mascall deposition is siltstone with some chert, coarse sandstone, the HRT, and RAFT. Beginning at the top of the section, the RAFT caps the entire site. The thickness of the RAFT at Hawk Rim is about 10m. Directly below the RAFT, sharing direct contact with the tuff, is a siltstone unit that is not very fossiliferous. There is a large, approximately 30m covered interval beneath the siltstone. The covered interval is thick colluvium and soil, obscuring rock exposures. Beneath the covered interval, sharing a 
direct contact with the covered interval, is the HRT. The HRT in Hawk Rim is the most well exposed section of the tuff, and it is about 5m thick. The HRT caps a thick siltstone deposit that is $45 \mathrm{~m}$ thick. Within that thick deposit, there are two distinct units, with the uppermost being fine sand at the base fining upward to siltstone right beneath the HRT. This unit is not particularly fossiliferous (Figures 9 and 10, letter D). Beneath this unit is the most fossiliferous part of Hawk Rim. It is approximately 35m of continuous silt with most fossils coming out of the middle of the unit (Figures 9 and 10, letter E). This unit shares a direct contact with underlying sandstone. The sandstone is coarse at the base, sharing a direct contact with underlying siltstone, and it fines upward to meet overlying siltstone. The sandstone is bedded and blueish in color. This sandstone is a definitive marker bed that can be traced to the eastern side of the study area, in South Fork East. Beneath the sandstone is another marker bed, Double Tuff. Double Tuff is only identifiable in Hawk Rim so far, and it is a bright white tuffaceous layer that sits atop a diatomaceous chert deposit. This chert deposit can be correlated with the chert deposit in Twin Buttes (Figures 7-10). Finally, beneath the chert marker bed is more siltstone that is characteristic of the Mascall.

Moving east, the next field site is Twin Buttes (Figures 2 and 8). Capping the Twin Buttes stratigraphic column is the RAFT, which is about $10 \mathrm{~m}$ thick. There is a 60m covered section on a steep hill directly beneath the exposure of the RAFT. Once rock becomes exposed under the covered interval, there is a thin, laminated mudstone that is about $1 \mathrm{~m}$ thick. Sharing a direct contact with the overlying mudstone is an ashy siltstone. This unit is not particularly fossiliferous, but the siltstone unit beneath the ashy siltstone is the most fossiliferous section of Twin Buttes (Figures 6 and 7, letter 
D). Beneath the fossiliferous siltstone unit is a 5m exposure of the Hawk Rim Tuff (HRT). The exposure is in a gulley, and a bit more difficult to identify compared to the exposure of the HRT at Hawk Rim, but the lithology matches. Sharing a direct contact with the overlying HRT is another thick siltstone deposit that is similar in deposition as the fossiliferous siltstone above the HRT, but this siltstone unit is not particularly fossiliferous in comparison. This unit is about $25 \mathrm{~m}$ thick and continuous. There is a small, 5m, covered interval under the siltstone, which shares a direct contact with chert deposits at the base of the section. Finally, the contact with the CRBG is visible at Twin Buttes. The measured section of CRBG is about $5 \mathrm{~m}$ thick.

The measured stratigraphic section at Cave Basin is about 100m thick in total. The top of Cave Basin, similar to Hawk Rim and Twin Buttes, is the RAFT which is about $10 \mathrm{~m}$ thick. Beneath the RAFT, sharing a direct contact with the tuff, is a thick siltstone deposit that changes in characteristics through its 75m deposition (Figures 4 and 5, letters B, C, D). The top section of the siltstone unit is fossiliferous and shares a gradational contact with underlying ashy siltstone. The ashy siltstone is not particularly fossiliferous. Beneath the ashy siltstone is more siltstone that is fossiliferous. This fossiliferous siltstone shares a direct contact with the HRT, which is about $5 \mathrm{~m}$ thick in Cave Basin. The base of the Cave Basin section is $5 \mathrm{~m}$ more of siltstone that is not particularly fossiliferous but does have relatively high organic content. Moving down the hillslope in Cave Basin, there is no exposure of the CRBG.

South Fork West is about $120 \mathrm{~m}$ of section in total, but $60 \mathrm{~m}$ of that section is covered with no exposed rock. This section is relatively incomplete, but is important because it is capped by a different unit, not the RAFT, but the Divine Canyon Ash Flow 
Tuff (DAFT) (Figures 10 and 11, letter A). Directly below the DAFT is a small, 4m, section of covered interval with two approximately $1 \mathrm{~m}$ thick tuffaceous siltstone units. These tuffaceous siltstone units break up the covered interval, but are not fossiliferous. Beneath the largest covered interval, which is $40 \mathrm{~m}$ thick, is fossiliferous siltstone with interbedded tuffaceous layers. The siltstone and tuffaceous siltstone make up the rest of the measured section.

Finally, the easternmost section, South Fork East, is a total of 120m thick. The capping unit in South Fork East is the Tertiary Olivine Basalt (TOB). The TOB is not described anywhere else in the study area (Figures 12 and 13, letter A). Directly beneath the TOB is the RAFT, which is about $5 \mathrm{~m}$ thick in this section. There is a steep section of hill that is covered in colluvium and no rock units could be described there. The covered interval is about $20 \mathrm{~m}$ thick. Sharing a direct contact with the covered interval is the unknown tuff, which is hypothesized to be either the HRT or a new tuff deposited extremely locally. Beneath the unknown tuff is a $6 \mathrm{~m}$ thick cross bedded coarse sandstone, which shares a direct contact with about $47 \mathrm{~m}$ of siltstone, which has been split into three distinct units. The uppermost siltstone unit is not particularly fossiliferous, and shares a direct contact with underlying siltstone that coarsens upward to reach sand sized grains. Under that unit is another siltstone unit that is fossiliferous and coarsens upwards to fine sand sized. Fossils have been identified in all $8 \mathrm{~m}$ of this unit of siltstone (Figures 13 and 14, letter G.) Beneath the fossiliferous siltstone is medium grained sandstone that is about $1 \mathrm{~m}$ thick. The sandstone is massive and without sedimentary structures. 
Sharing a direct contact with overlying sandstone is another thick section of siltstone that is fossiliferous as well. Beneath the fossiliferous siltstone is more siltstone, that is about $20 \mathrm{~m}$ thick in total with interbedded tuffaceous siltstone. (Figures 12 and 13, letter J). 


\section{DISCUSSION}

\section{Description of the Crooked River Mascall}

One of the primary goals of this project is to more completely describe the characteristics of the Crooked River Mascall Formation. There are certain qualities of the Mascall that span all sites and should be considered key characteristics of the formation. Across the Crooked River Basin, the major tie between all the sites is that the Mascall is a light tan to brown colored siltstone with some resistant tuffaceous beds interspersed with less resistant siltstone. The lower section of the Crooked River Mascall commonly contains chert and diatomite deposits, as seen in Hawk Rim and Twin Buttes. For the most part, the induration of the siltstone varies in the form of direct contacts between units, defined breaks between less indurated and more indurated silt, though there are a few sections that coarsen upwards, as seen in Cave Basin and South Fork East. Generally, the HRT is positioned between segments of the Mascall siltstone, suggesting that fluvial deposition of the Mascall continued as usual after the deposition of the HRT.

\section{Paleo-Depositional Environments}

The measurement and description of stratigraphic columns at the five field sites allow for deeper analysis of microclimates within the basin. Based on the thickness and sedimentary structures visible, inferences may be made about the depositional environment of that particular area of the basin. Throughout the basin, most of the depositional characteristics that speak to the microenvironments of the sites are confined enough to be only visible in each particular site. 
At Twin Buttes in the northwestern side of the study area, there is a significant chert deposit at the base of the column, sharing a direct contact with the CRBG. This deposit is bedded chert, as opposed to nodular chert, and is diatomaceous in nature. The diatomaceous chert found in Twin Buttes is dense and light whitish yellow to orange in color. The presence of diatomaceous bedded chert suggests that, at one point in Twin Buttes’ history, the area featured deep enough water to result in chert formation. Another notable piece of the Twin Buttes section is the thin laminated mudstone that sits atop the Mascall Formation and below the covered unit that precedes the RAFT. Mudstones form in environments that feature enough fine sediment and calm water to result in suspension settling of the sediment. The presence of mudstone suggests a lacustrine, river bank, or mixed environment of rivers and small lakes at some point after the deposition of the Mascall. The fact that fossiliferous siltstone is bounded by chert below and mudstone above suggests that there was both a wet and dry period of Twin Buttes’ history.

Similar wet and dry periods can be observed at Hawk Rim, located on the southeastern side of the study area. Similar to Twin Buttes, Hawk Rim also has a diatomaceous chert deposit and a diatomite deposit (Figures 9 and 10). The difference between a diatomaceous chert deposit and a diatomite deposit is that diatomaceous chert deposits are beds of diatomite that have converted the diatomite into denser chert material (Boggs, 2012). It is not uncommon for volcanic provinces (such as the Crooked River Basin) which experienced the large scale basaltic flooding to be associated with lacustrine diatomite. The diatomaceous deposits in Hawk Rim are positioned stratigraphically lower in the Mascall Formation (Figures 9 and 10, letter I). 
This position of the possibly lacustrine rock is consistent with the diatomaceous deposits found at Twin Buttes, both are positioned low in the Mascall Formation. The positioning of these deposits below the Mascall suggests that the CRBG altered the landscape to create inland water-logged areas where these sediments could form.

An interesting connection between Twin Buttes and Hawk Rim is that they are both located on the same side of the basin and exhibit similar wet and dry altered settings by the diatomaceous deposits. Perhaps this correlation has something to do with the topography of the basin, direction of sediment influx, and depositional direction of the CRBG on the western side of the basin. Moving from west to east in the field sites, we see that the thicker deposits are on the western side, Hawk Rim and Twin Buttes, which suggests that the sediment flux into the basin is greatest on the western side, and the source of sediment flux came from the northwestern section of the study area. (Figures 2, 7, and 9).

Focusing on the eastern side of the basin, the three field sites are Cave Basin, South Fork East, and South Fork West. Cave Basin is a valuable field site because it has a thick, relatively uninterrupted depositional history of the Mascall. Although the Mascall section is well-exposed at this site, there is really no defining feature to allow for hypothesis about microclimate. By the absence of chert and diatomite deposits, Cave Basin appears to have been consistently dry and, judging by the quality of fossil prospecting at this site, an ideal environment for many mammals of the midMiocene. (Figures 4 and 5, letter D).

Also on the eastern side of the study area are South Fork East and West. Both have several tuffaceous siltstone interbedded in the looser, less consolidated silt of the 
Mascall. At South Fork West, the tuffaceous siltstone layers are near the bottom of the measured section and are each about a meter thick. Higher in section, there are large intervals that are covered in colluvium, but some tuffaceous siltstone layers that are visible (Figures 10 and 11). South Fork West is entirely siltstone and fine sandstone with no sedimentary structures to indicate paleoenvironment. This is a good reason to have another field site in the area, and South Fork East is very close to South Fork West. South Fork East provides some insight into depositional history of the region beyond the siltstone of South Fork West.

South Fork East has several sandstone layers and a bedded conglomerate that sit high in the section in the Mascall. With more time and resources, thin sections of the conglomerate and sandstones should be created to describe these units in greater clarity. Classifying the sandstones chemically and mineralogically provides more insight to the microclimate of the site. Besides the sandstones, there is an approximately one meter thick cross-bedded conglomerate that is important to look at when hypothesizing about paleoenvironment. The conglomerate is clast supported and likely of fluvial origin, due to the evidence of cross-bedding.

\section{Correlation Hypotheses}

Working with the description of the unknown tuff found in South Fork East, and the descriptions of the HRT and DAFT, there are several possibilities for the columns' correlations. For each theoretical scenario, we have created a fence diagram to display how the columns would be connected around the basin. Creating fence diagrams ties the simplified stratigraphic columns together using correlateable units; because we do not 
know the identity of the tuff in South Fork East without further chemical testing, the work we can do right now is preliminary and speculative.

The first hypothesis for the connection of the stratigraphic columns between the five field sites in the Crooked River Basin is that the unknown tuff matches the HRT (Figure 14). HRT is best displayed in Hawk Rim, this is where the tuff is thickest and most prominently exposed. The description from the field of the HRT is "[a] welded ash flow tuff, weathered surface light gray with some dark organic material; fresh surface medium gray with pumice fragments and black obsidian fragments; very crumbly and almost sandy ash surface that sparkles in the sunlight; when hit with a hammer it is soft and does not ring...” (Figure 8). The general feel of the HRT, in terms of its hardness and sandy ash weathered surface texture is very similar to the unknown tuff. Both the unknown tuff and HRT are light grey in color on both the weathered and fresh surface, both are soft under a hammer, when compared to other welded tuffs in the area such as the DAFT and RAFT, and both have pumice fragments. Based on the physical descriptions alone, it seems that the HRT is the most likely candidate for a match with the unknown tuff.

The other line of evidence that can be used to determine the match of the unknown tuff to HRT is the stratigraphic position of the HRT in the sites across the basin compared to the stratigraphic location of the unknown tuff. For example, if Double Tuff could be found in South Fork East; we would expect the HRT to be stratigraphically above Double Tuff. If the unknown unit was below Double Tuff, it would not make sense in depositional history for the unknown tuff to be HRT. Double Tuff is not seen in South Fork East, that is just an example of how stratigraphic 
correlation can be useful for understanding the identity of an unknown unit.

Stratigraphically, the HRT lies lower in section than the DAFT, RAFT, and TOB, but above Double Tuff. In Hawk Rim, where Double Tuff sits below HRT and the RAFT sits above HRT.

The HRT is exposed in three of the five field sites. In Twin Buttes, it is about 50m up section, with siltstone, chert, and the CRBs below it; in Cave Basin, it is about 5m up section with siltstone below it; and in Hawk Rim, it is 75m up section with mostly siltstone beneath it, with some sandstone, Double Tuff, and chert below the siltstone. Using the characteristics of other sections containing the HRT, we can compare to what we see at South Fork East. At South Fork East, the unknown tuff is about $85 \mathrm{~m}$ up section with conglomerate directly beneath it, and mostly siltstone of varying characteristics making up the bottom of the section. With the exception of Cave Basin, the unknown tuff seems to fall in the same range of depositional depth as the other sites with the HRT, it seems to fall in a similar sequence, stratigraphically, as Twin Buttes and Hawk Rim.

As shown in Figure 14, if the unknown tuff was in fact the HRT, it would connect four of the five field sites. The HRT has not been identified in South Fork West, but it is present in all other field sites. It could be suggested that with a greater coverage of the field site at Crooked River West, perhaps the HRT is deposited there; there are many meters of covered interval that, with more time and attention, could possibly be filled in with more time in the field.

The second possibility is that the unknown tuff does not match the HRT, but is an entirely new unit that has not been identified in the area (Figure 15). There is a 
chance that some localized depositional event occurred that created a resistant bed that only appears in South Fork East and not any of the other sites. There is also a possibility that this unknown tuff could exist in South Fork West, or the upper sections of Twin Buttes or Hawk Rim because there is covered interval in those columns. More time in the field could reveal something we have yet to see in one or more of those sites. We see this as a less-likely possibility because the lithology of the unknown tuff seems to fairly closely match that of the HRT. It is important to acknowledge, though, that there could be a possibility of chemical analysis showing that the unknown tuff is not a match to either of those units, so we present it as a possibility.

We acknowledge that there are other marker beds in the region, namely the CRBG, Double Tuff, the DAFT, the RAFT, and the TOB, but all of these units are not possible matches for the unknown tuff. Where the unknown tuff is exposed, the CRBG, RAFT, and TOB are all exposed, so there is no way that the unknown tuff could match any of those, stratigraphically. The unknown tuff could not be the DAFT because the DAFT is stratigraphically above the Mascall Formation and does not match the description of the unknown tuff. The only other remaining possibility is Double Tuff, which is only exposed in Hawk Rim. It does not make sense for the unknown tuff to be a match to Double Tuff because it is too high in section for the units to correlate. Additionally, Double Tuff is drastically different in appearance compared to the unknown tuff.

\section{Further Directions}

With more time and resources, there are several future directions for this project. The first direction would be to create new field sites further north to try to uncover new 
rock exposures to create more complete stratigraphic columns. The five field sites that have already been defined and examined in this project have been studied for the past ten field seasons, so revisiting those sites would not be particularly useful.

The second direction is the chemical analysis of the unidentified tuff from South Fork East. If there is a confirmed match with either the HRT or DAFT, more convincing arguments could be made for the connections between columns around the basin. The third direction is to create thin sections for each of the samples to describe the sedimentological characteristics in further detail for some of the notable units including the blue sandstone in Hawk Rim and the cross-bedded conglomerate and sandstones in South Fork East. To perform these analyses, thin sections should be created from both of these units to determine the mineral and chemical composition of the sandstones and conglomerate. The purpose of compiling this additional information is to help with the placement of these beds in a narrative about the paleoenvironment of their deposition.

The fourth direction is to begin performing a full basin analysis on the Crooked River Basin, including analysis of the current topography within the basin, paleotopography based on the movement of sediment modeled by measured stratigraphic columns, and more detail on how sedimentation likely occurred within the basin. 


\section{CONCLUSION}

This project marks the beginning of work in the Crooked River Basin Mascall formation. Although there is a lot of room for further study and advancement of this project, there are some goals that have been accomplished in this work so far. The five

field sites, Twin Buttes, Cave Basin, Hawk Rim, South Fork West, and South Fork East have been defined and thoroughly described over the years, with this work being the first to include all five sites. The Mascall has been identified and compared to the John Day type-area Mascall, and the Crooked River Mascall has been prospected to gain a sense of the paleoecology of the region and how it may differ from the John Day Mascall. The correlateable tuffs in the region have been defined and dated, with the exception of the unknown tuff in South Fork East.

This project addressed the status of the sediment accumulation in the Crooked River Basin and determined, based on the stratigraphic columns measured, that the flow of sediment is coming into the basin from the Northwest, leading to greater accumulation on the western side of the basin. Each field site's microclimate has been analyzed based on sedimentary structures seen there, and the most fossiliferous sections of each site have been identified. 


\section{Figures}

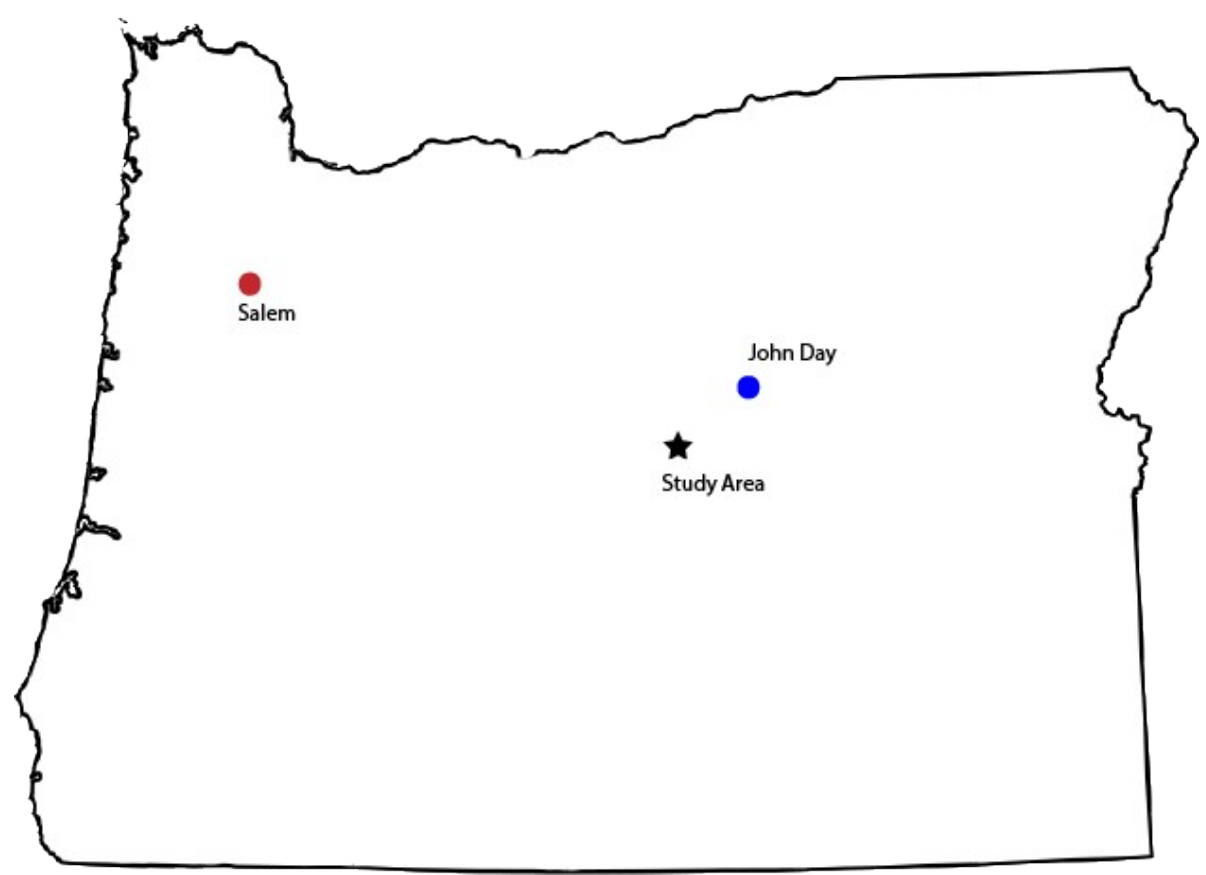

Figure 1: Map of Oregon with Salem, John Day, and the study area labeled

A simple way to become oriented with the study area is to have an expanded view of the state and where it is located. The Crooked River Basin is located southwest of the John Day Basin, which is well known due to the John Day National Monument. Salem is shown with a red dot, John Day with a blue dot, and the study area with a black star. 


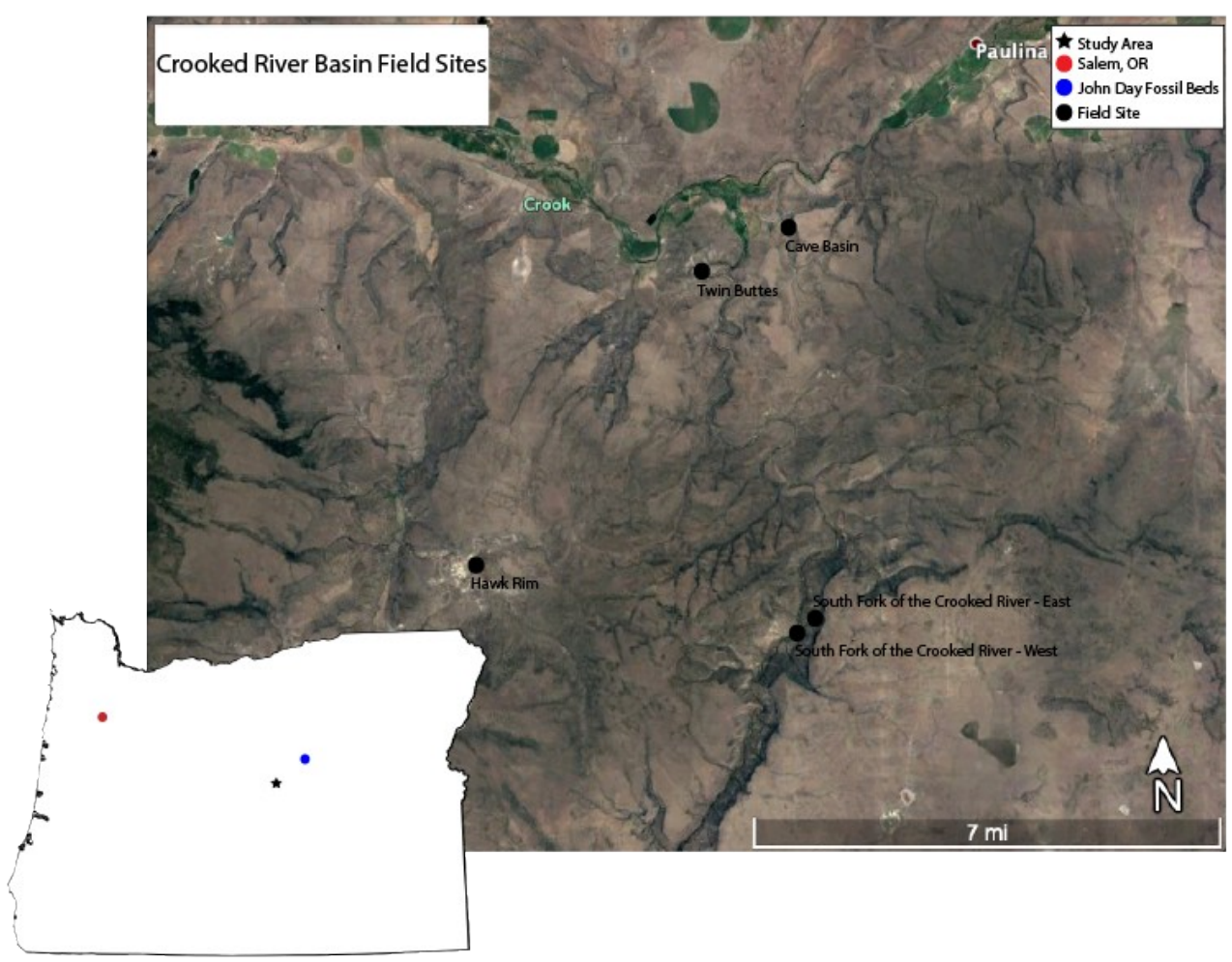

Figure 2: Map of the Study Area

This figure provides context for the study area. The map of Oregon in the left corner of the figure shows Salem, OR in red, the John Day Fossil Beds in blue, and the study area is marked by a black star. The GoogleEarth map shows the specific locations of field sites within the study area. Twin Buttes is located in the northwest, Cave Basin in the northeast, Hawk Rim in the southwest, and South Fork of the Crooked River East and West in the southeast. 


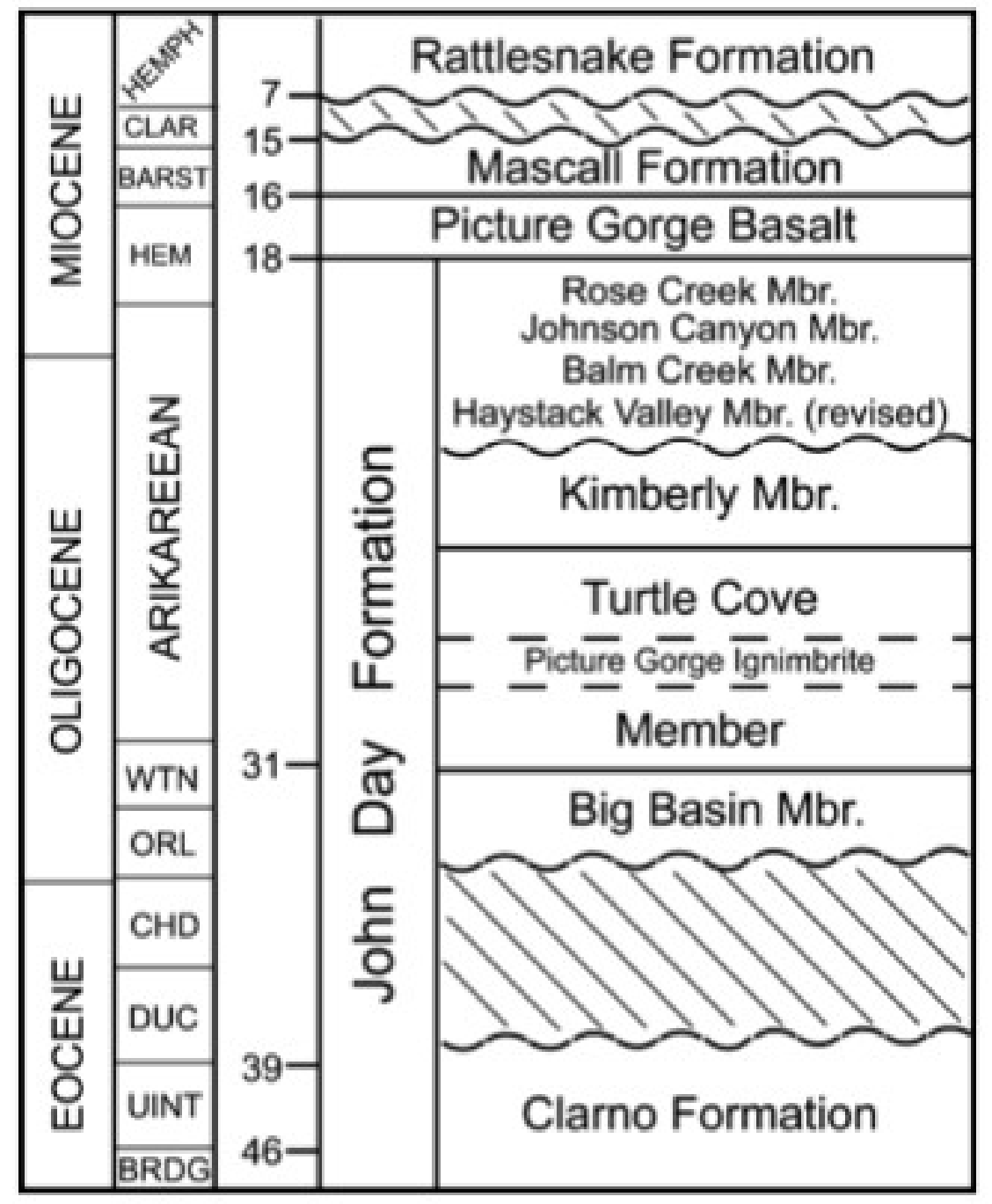

Figure 3: Simplified Stratigraphy of the John Day Sequence

This is Figure 1 from Albright, et al.'s 2004 paper, “Revised chronostratigraphy and biostratigraphy of the John Day Formation (Turtle Cove and Kimberly Members), Oregon, with implications for updated calibration of the Arikareean North American Land Mammal Age.” This is an important background piece of information for understanding the general stratigraphy of John Day, which shares some units with Crooked River. Specifically, in Crooked River we see the Picture Gorge Basalt, Mascall Formation, and the Rattlesnake Formation. 


\begin{tabular}{|l|l|}
\hline Cave Basin & Unit Description \\
\hline Anit Label & $\begin{array}{l}\text { Rattlesnake Ash Flow Tuff: thickness 85m-96m; welded ash flow } \\
\text { tuff; weathered surface is dark brown color, fresh surface is light } \\
\text { tan/grey color; mm sized off-white to weathered orange pumice } \\
\text { clasts, some glass and fiamme, matrix is well indurated; shares a } \\
\text { direct contact with underlying siltstone unit. }\end{array}$ \\
\hline B & $\begin{array}{l}\text { Siltstone: thickness 62m-85m; extremely similar to unit C without } \\
\text { abundant root traces; weathered surface is light tan, fresh surface is } \\
\text { greyish brown; begins as fairly well indurated siltstone with about } \\
\text { 5\% calcareous nodules; fossiliferous; shares direct contact with } \\
\text { overlying RAFT and gradational contact with underlying ashy } \\
\text { siltstone. }\end{array}$ \\
\hline C & $\begin{array}{l}\text { Siltstone: thickness 40m-62m; ashy siltstone; weathered surface is } \\
\text { light grey; fresh surface is darker grey; shares gradational contact } \\
\text { with underlying siltstone and overlying siltstone. }\end{array}$ \\
\hline D & $\begin{array}{l}\text { Siltstone: thickness 9m-40m; weathered surface is light tan, fresh } \\
\text { surface is greyish brown; begins as fairly well indurated siltstone } \\
\text { with about 5\% calcareous nodules and abundant root traces; } \\
\text { fossiliferous; shares gradational contact with above ashy siltstone. }\end{array}$ \\
\hline F & $\begin{array}{l}\text { Hawk Rim Tuff: thickness 5m-9m; welded ash flow tuff, weathered } \\
\text { surface light grey with some dark organic material; fresh surface } \\
\text { medium grey with pumice fragments and black obsidian fragments; } \\
\text { very crumbly and almost sandy ash surface that sparkles in the } \\
\text { sunlight; when hit with a hammer it is soft and does not ring; shares } \\
\text { a direct contact with overlying and underlying siltstone units. }\end{array}$ \\
$\begin{array}{l}\text { Siltstone: thickness 0m-5m; weathered surface is light tan, fresh } \\
\text { surface is greyish brown; not well indurated, heavily reworked by } \\
\text { vegetation; when broken it crumbles into cm sized blocky peds; } \\
\text { shares a direct contact with the overlying Hawk Rim Tuff. }\end{array}$ \\
\hline
\end{tabular}

Figure 4: Cave Basin Unit Descriptions 


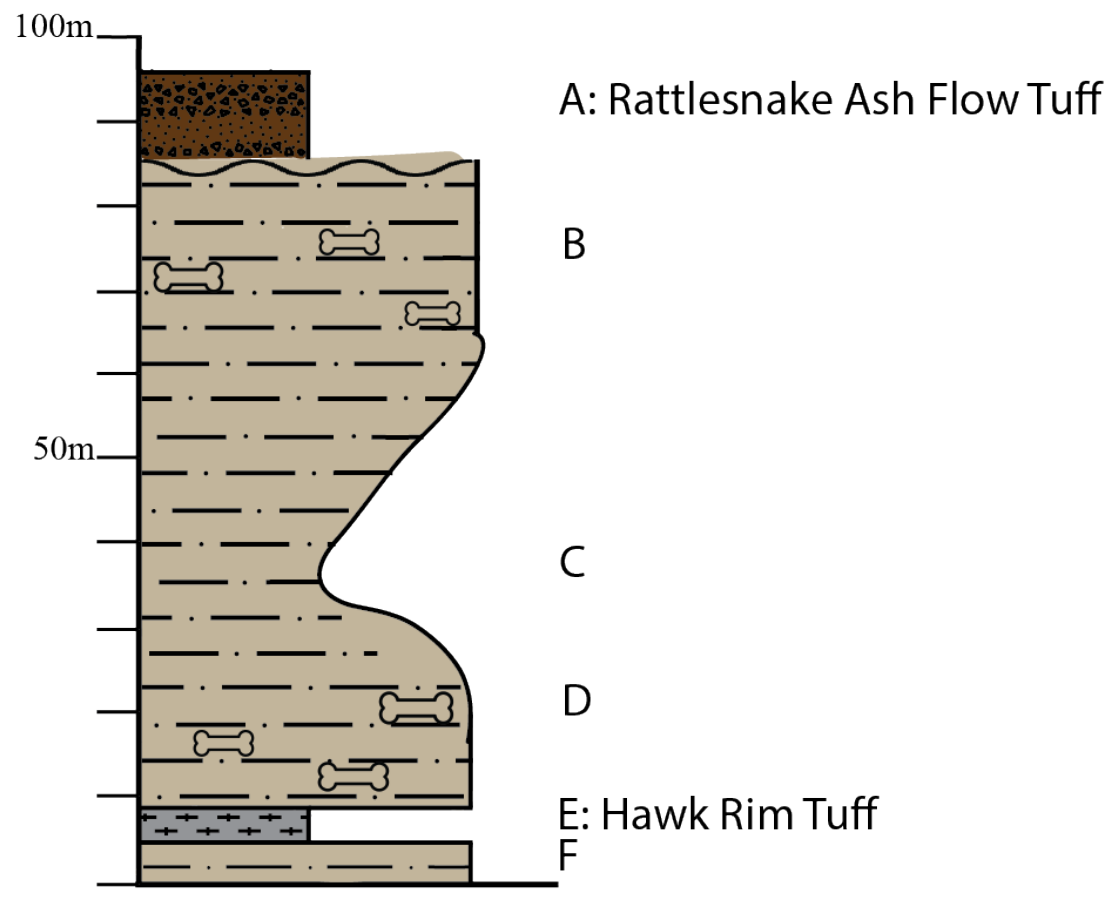

Figure 5: Cave Basin Stratigraphic Column

The vertical line is a measurement of distance from the bottom of the measured section; the horizontal line is a measure of grain size, increasing from left to right. Cave Basin is a quality exposure of the Mascall Formation that includes an exposure of the Hawk Rim Tuff and is capped by the Rattlesnake Ash Flow Tuff. The thickness of the section is about 95 meters in total. At the base of the section, there is about half a meter of siltstone that shares a sharp contact with colluvium below (F). Above the siltstone, there is a half meter thick exposure of the Hawk Rim Tuff, which is a useful tool for correlating the column in Cave Basin with other columns in the study area (E). The Hawk Rim Tuff shares a sharp contact with overlying siltstone, which is well indurated and has about 5\% calcareous nodules (D). The color of the siltstone's weathered surface is light tan, and the fresh surface is grey. The siltstone has a higher ash content moving upwards in section, creating an ashy siltstone (C). The ashy siltstone gradationally transitions to a non-ashy siltstone with abundant root traces that shares a sharp contact with the overlying Rattlesnake Ash Flow Tuff (B). The Rattlesnake Ash Flow Tuff is a welded tuff with a dark brown weathered surface and a light tan/grey fresh surface with mm sized off-white to weathered orange pumice clasts, some glass and fiamme, and a well indurated matrix (A). 


\begin{tabular}{|c|c|}
\hline \multicolumn{2}{|c|}{ Twin Buttes } \\
\hline Unit Label & Unit Description \\
\hline A & $\begin{array}{l}\text { Rattlesnake Ash Flow Tuff: thickness } 151 \mathrm{~m}-160 \mathrm{~m} \text {; welded ash flow } \\
\text { tuff; weathered surface is dark brown color, fresh surface is light } \\
\text { tan/grey color; mm sized off-white to weathered orange pumice } \\
\text { clasts, some glass and fiamme, matrix is well indurated; shares a } \\
\text { direct contact with underlying covered interval. }\end{array}$ \\
\hline B & $\begin{array}{l}\text { Mudstone: thickness } 87 \mathrm{~m}-90 \mathrm{~m} \text {; weathered and fresh surface dark } \\
\text { brown; thinly laminated mudstone; scarce root traces; minimally } \\
\text { reworked; shares a direct contact with the underlying ashy siltstone } \\
\text { and the overlying covered interval. }\end{array}$ \\
\hline $\mathrm{C}$ & $\begin{array}{l}\text { Siltstone with interbedded ash: thickness } 76 \mathrm{~m}-87 \mathrm{~m} \text {; poorly } \\
\text { indurated ashy siltstone; both weathered surface and fresh surface } \\
\text { are light tan; plentiful root traces; shares transitional contact with } \\
\text { underlying siltstone and overlying mudstone. }\end{array}$ \\
\hline $\mathrm{D}$ & $\begin{array}{l}\text { Siltstone: thickness } 56 \mathrm{~m}-76 \mathrm{~m} \text {; poorly indurated siltstone; weathered } \\
\text { surface is light tan, fresh surface is greyish brown; with about } 5 \% \\
\text { calcareous nodules and abundant root traces; shares direct contact } \\
\text { with above Hawk Rim Tuff, and gradational contact with below } \\
\text { covered interval. }\end{array}$ \\
\hline $\mathrm{E}$ & $\begin{array}{l}\text { Hawk Rim Tuff: thickness 50m-56m; welded ash flow tuff, } \\
\text { weathered surface light grey with some dark organic material; fresh } \\
\text { surface medium grey with pumice fragments and black obsidian } \\
\text { fragments; very crumbly and almost sandy ash surface that sparkles } \\
\text { in the sunlight; when hit with a hammer it is soft and does not ring; } \\
\text { shares a direct contact with underlying and overlying siltstone units. }\end{array}$ \\
\hline $\mathrm{F}$ & $\begin{array}{l}\text { Siltstone: thickness } 23 \mathrm{~m}-50 \mathrm{~m} \text {; more poorly indurated siltstone; } \\
\text { weathered and fresh surface are dark tan with abundant root traces; } \\
\text { shares direct contact with overlying ashy siltstone and direct contact } \\
\text { with underlying Hawk Rim Tuff. }\end{array}$ \\
\hline $\mathrm{G}$ & $\begin{array}{l}\text { Chert: thickness 5m-19m; weathered surface light yellowish orange; } \\
\text { fresh surface whitish orange; irregularly spaced wavy greyish beds } \\
\text { about } 20 \mathrm{~cm} \text { thick; direct contact with underlying CRBG; jagged and } \\
\text { irregular direct contact with covered interval above. }\end{array}$ \\
\hline $\mathrm{H}$ & $\begin{array}{l}\text { Columbia River Basalts: thickness } 0 \mathrm{~m}-5 \mathrm{~m} \text {; weathered surface } \\
\text { reddish brown; fresh surface black aphanitic basalt with small, mm } \\
\text { scale, plagioclase phenocrysts in } \sim 40 \% \text { abundance; tabular jointing; } \\
\text { shares a direct contact with overlving chert. }\end{array}$ \\
\hline
\end{tabular}

Figure 6: Twin Buttes Unit Descriptions 


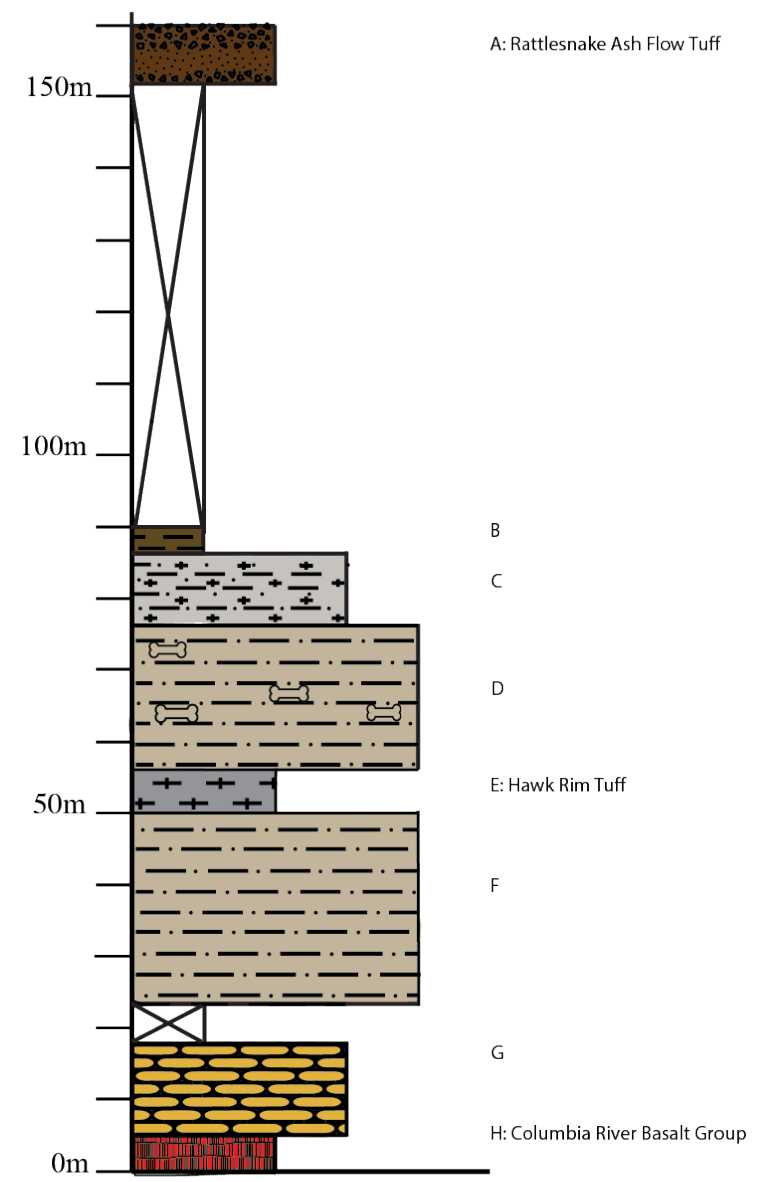

Figure 7: Twin Buttes Stratigraphic Column

Beginning at the top of the section is about 10m of RAFT capping the section (A). Beneath the RAFT, sharing a direct contact is $60 \mathrm{~m}$ of covered interval atop the next unit which is a thin, laminated mudstone (B). Sharing a direct contact with the mudstone is approximately $10 \mathrm{~m}$ of ashy siltstone (C). The most fossiliferous portion of Twin Buttes is below the ashy siltstone, and is about $20 \mathrm{~m}$ of siltstone with no identifiable sedimentary structures (D). This sits atop the exposure of the HRT, which is about $5 \mathrm{~m}$ thick $(\mathrm{E})$. Beneath the HRT is a siltstone unit that is not particularly fossiliferous (F). There is a small covered interval that shares a direct contact with yellowish orange bedded chert below $(\mathrm{G})$, which makes direct contact with the CRBG (H). 


\begin{tabular}{|c|c|}
\hline \multicolumn{2}{|l|}{ Hawk Rim } \\
\hline Unit Label & Unit Description \\
\hline A & $\begin{array}{l}\text { Rattlesnake Ash Flow Tuff: thickness } 120 \mathrm{~m}-130 \mathrm{~m} \text {; welded ash flow } \\
\text { tuff; weathered surface is dark brown color, fresh surface is light } \\
\text { tan/grey color; mm sized off-white to weathered orange pumice } \\
\text { clasts, some glass and fiamme, matrix is well indurated. }\end{array}$ \\
\hline B & $\begin{array}{l}\text { Siltstone: thickness } 112 \mathrm{~m}-120 \mathrm{~m} \text {; thin, light brown siltstone, that } \\
\text { weathers to cm sized blocks; contains root traces, lithic fragments, } \\
\text { and pumice clasts that are mm in sized; shares a gradational contact } \\
\text { with below covered colluvium interval and a direct contact with } \\
\text { above RAFT. }\end{array}$ \\
\hline C & $\begin{array}{l}\text { Hawk Rim Tuff: thickness 75-80m; welded ash flow tuff, weathered } \\
\text { surface light grey with some dark organic material; fresh surface } \\
\text { medium grey with pumice fragments and black obsidian fragments; } \\
\text { very crumbly and almost sandy ash surface that sparkles in the } \\
\text { sunlight; when hit with a hammer it is soft and does not ring; shares } \\
\text { direct contacts with overlying and underlying units. }\end{array}$ \\
\hline $\mathrm{D}$ & $\begin{array}{l}\text { Siltstone: thickness } 65 \mathrm{~m}-75 \mathrm{~m} \text {; siltstone that shares a direct contact } \\
\text { with the underlying finer siltstone and a direct contact with the } \\
\text { overlying Hawk Rim Tuff; this siltstone is similar in color, with the } \\
\text { bottom of the unit a coarse, well indurated texture, fining upward to } \\
\text { a fine silt texture. }\end{array}$ \\
\hline $\mathrm{E}$ & $\begin{array}{l}\text { Siltstone: thickness } 30 \mathrm{~m}-65 \mathrm{~m} \text {; siltstone; weathered surface is orange } \\
\text { tan colored, fresh surface is tan colored; fossiliferous; the base of } \\
\text { the siltstone unit is tuffaceous siltstone that is well-indurated, that } \\
\text { shares a direct contact with above siltstone and underlying coarse } \\
\text { sandstone. }\end{array}$ \\
\hline $\mathrm{F}$ & $\begin{array}{l}\text { Coarse sandstone: thickness } 25 \mathrm{~m}-30 \mathrm{~m} \text {; coarse grained sandstone; } \\
\text { weathered surface is dark brown color, from afar it appears dark } \\
\text { grey and platy. Fines upward in section and displays cross bedded } \\
\text { structure; shares direct contacts with overlying and underlying units. }\end{array}$ \\
\hline $\mathrm{G}$ & $\begin{array}{l}\text { Siltstone: thickness } 20 \mathrm{~m}-25 \mathrm{~m} \text {; weathered surface is sandy brown, } \\
\text { fresh surface is tan with root traces and cracked texture; shares a } \\
\text { direct contact with underlying Double Tuff and direct contact with } \\
\text { overlying coarse sandstone unit. }\end{array}$ \\
\hline $\mathrm{H}$ & $\begin{array}{l}\text { Double Tuff: thickness } 18 \mathrm{~m}-20 \mathrm{~m} \text {; uffaceous layer with a white fresh } \\
\text { surface and yellowish white weathered surface; ferruginized root } \\
\text { traces; shares a direct contact with underlying siltstone and } \\
\text { overlying siltstone. }\end{array}$ \\
\hline I & $\begin{array}{l}\text { Diatomaceous chert: thickness } 12 \mathrm{~m}-18 \mathrm{~m} \text {; light whitish yellow in } \\
\text { color, shares a direct contact with underlying siltstone and overlying } \\
\text { double tuff. }\end{array}$ \\
\hline $\mathrm{J}$ & Siltstone: thickness $0 \mathrm{~m}-12 \mathrm{~m}$; siltstone, weathered surface is whitish \\
\hline
\end{tabular}


tan color, fresh surface is darker tan color; abundant root traces; no internal sedimentary structures; weathers to cm sized chunks when broken; shares a direct contact with overlying Double Tuff.

Figure 8: Hawk Rim Unit Descriptions

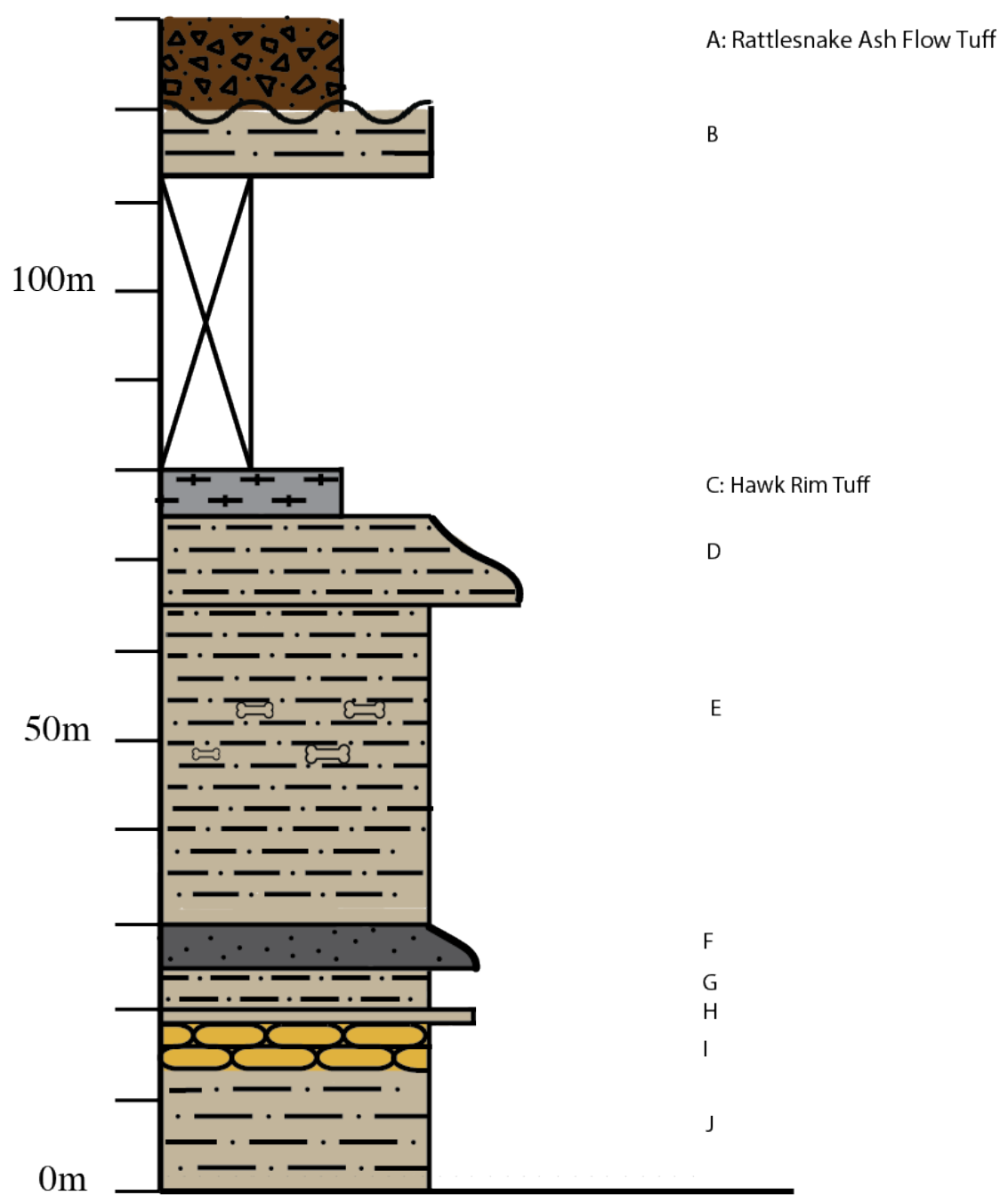


Figure 9: Hawk Rim Stratigraphic Column

Hawk Rim is a 130m thick section featuring correlateable units: the Rattlesnake Ash Flow Tuff (RAFT), Hawk Rim Tuff (HRT), coarse sandstone, and bedded diatomaceous chert. At the top of the section is a $10 \mathrm{~m}$ thick exposure of the RAFT (A) that shares a direct contact with $8 \mathrm{~m}$ of siltstone (B). Below the uppermost exposure of the siltstone is an approximately $30 \mathrm{~m}$ covered interval. Beneath the covered interval, the next exposure is a $5 \mathrm{~m}$ section of the HRT that can be correlated to other sections in the study area (C). Under the HRT is $45 \mathrm{~m}$ of siltstone that is split into two units (D and E). The upper unit of siltstone coarsens upward to become fine sand grain size. Below that siltstone unit is a more fossiliferous siltstone that neither coarsens nor fines upwards (E). Below that unit is a coarse sandstone that can also be correlated to other sections across the study area (F). Sharing a direct contact with the overlying sandstone is more siltstone that is not particularly fossiliferous (G). Double Tuff, which is only identified in Hawk Rim is below that siltstone $(\mathrm{H})$. Beneath Double Tuff is bedded chert that is correlateable to Twin Buttes, another site in the study area (I). Finally, at the base of the section is more siltstone that is not fossiliferous (J).

\begin{tabular}{|l|l|}
\hline \multicolumn{2}{|l|}{ South Fork of the Crooked River - West } \\
\hline Unit Label & Unit Description \\
\hline A & $\begin{array}{l}\text { Divine Canyon Ash Flow Tuff: light grey ash flow tuff with } \\
\text { uniform matrix and haloed crystals; denser than RAFT; shares a } \\
\text { direct contact with the underlying covered interval. }\end{array}$ \\
\hline B & $\begin{array}{l}\text { More tuffaceous fine sandstone; light tan fresh and weathered } \\
\text { surface; weathered surface is light medium greyish white and } \\
\text { cobbled on the outside; fresh surface is chocolate brown; shares a } \\
\text { direct contact with the covered interval above. }\end{array}$ \\
\hline C & $\begin{array}{l}\text { Less consolidated fine siltstone, no sedimentary structures; } \\
\text { fossiliferous; shares a direct contact with underlying tuffaceous } \\
\text { siltstone and overlying tuffaceous sandstone. }\end{array}$ \\
\hline D & $\begin{array}{l}\text { Tuffaceous fine sand sized material; weathered surface is tan brown } \\
\text { in color; some larger calcareous nodules present; shares a direct } \\
\text { contact with underlying siltstone and a direct contact with overlying } \\
\text { fine siltstone. }\end{array}$ \\
\hline E & $\begin{array}{l}\text { Light brown siltstone that weathers into blocky 3cm pieces, few } \\
\text { visible root traces and few } ~ 1 c m \text { calcareous nodules; shares a direct } \\
\text { contact with the overlying tuffaceous siltstone. }\end{array}$ \\
\hline
\end{tabular}

Figure 10: South Fork of the Crooked River - West Unit Descriptions 


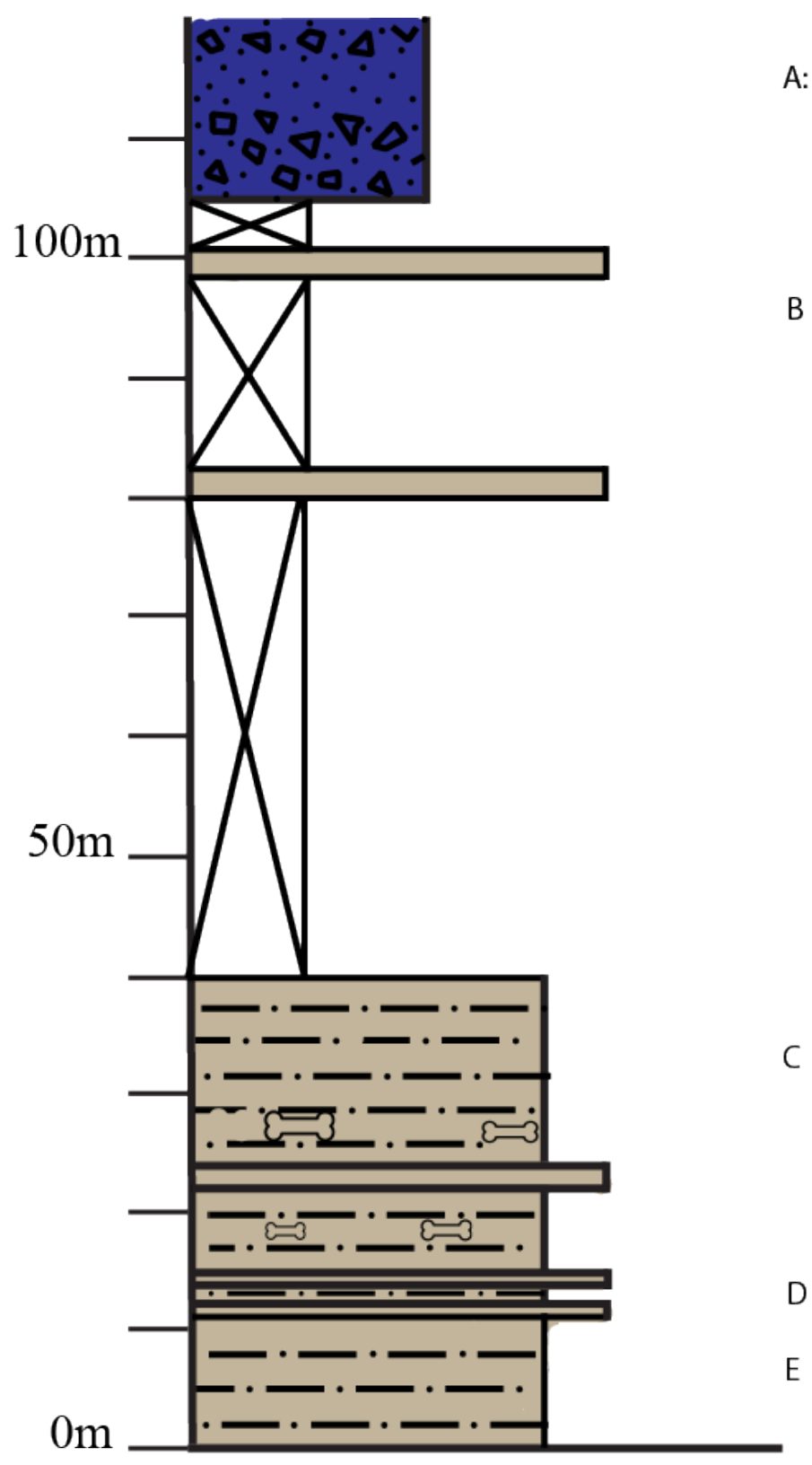

Figure 11: South Fork of the Crooked River - West Stratigraphic Column 
South Fork of the Crooked River - West is a 120m thick column that includes the

Divine Canyon Ash Flow Tuff (DAFT) marker bed, that is about 15m thick (A).

Beneath the DAFT, there is a small covered interval that is about $5 \mathrm{~m}$ thick, followed by

a set of two tuffaceous siltstones that are the same in description and neither are

fossiliferous and is only exposed for about $1 \mathrm{~m}$ each (B). There is more covered interval

between the two similar tuffaceous siltstones and underneath them, covering about $40 \mathrm{~m}$

of section. Beneath the covered interval is more siltstone, this time more fossiliferous

(C). Under the fossiliferous portion of South Fork West, there is more tuffaceous

siltstone (D) and non-tuffaceous siltstone (E).

\begin{tabular}{|l|l|}
\hline South Fork of the Crooked River - East \\
\hline Unit Label & Unit Description \\
\hline A & $\begin{array}{l}\text { Tertiary Olivine Basalt (TOB): thickness 115m-120m; aphanitic } \\
\text { porphyritic basalt with dark grey groundmass and 2mm olivine } \\
\text { phenocrysts; 1mm needle like feldspar phenocrysts; up to 30\% } \\
\text { vesicles; secondary calcite found in vesicles; prominent columnar } \\
\text { jointing that weathers to angular talus; shares a direct contact with } \\
\text { the underlying RAFT. }\end{array}$ \\
\hline B & $\begin{array}{l}\text { Rattlesnake Ash Flow Tuff (RAFT): thickness 110m-115m; welded } \\
\text { ash flow tuff; weathered surface is dark brown color, fresh surface } \\
\text { is light tan/grey color; mm sized off-white to weathered orange } \\
\text { pumice clasts, some glass and fiamme, matrix is well indurated. }\end{array}$ \\
\hline C & $\begin{array}{l}\text { Unknown Tuff: thickness 87m-88m; resistant grey ashy bed; about } \\
\text { 1m thick; up to 20\% pumice in cm sized pieces; shares a direct } \\
\text { contact with the underlying cross bedded sandstone unit and a direct } \\
\text { contact with the overlying covered interval. }\end{array}$ \\
\hline D & $\begin{array}{l}\text { Coarse cross-bedded sandstone: thickness 80m-87m; trough cross- } \\
\text { bedded sandstone; weathered surface is mostly medium grey, fresh } \\
\text { surface is multicolored grains with an overall light grey color; 50\% } \\
\text { reworked pumice, crystals, and reworked basalt; sandstone very } \\
\text { gradually fines upwards; shares a direct contact with overlying } \\
\text { unknown tuff and underlying siltstone. }\end{array}$ \\
\hline E & $\begin{array}{l}\text { Siltstone: thickness 67m-80m; poorly consolidated tan siltstone; } \\
\text { weathered surface is light tan, fresh surface is brownish tan; } \\
\text { crumbles into cm sized blocks when broken; some organic material } \\
\text { in the form of root traces, shares a direct contact with underlying } \\
\text { sandstone and overlying cross bedded coarse sandstone. }\end{array}$ \\
\hline
\end{tabular}




\begin{tabular}{|l|l|}
\hline $\mathrm{F}$ & $\begin{array}{l}\text { Siltstone: thickness 55m-67m; the base of this unit is similar to unit } \\
\text { E, a tan siltstone with some root traces; about 5m into this unit, the } \\
\text { siltstone becomes fine sand grain sized material with a similar color } \\
\text { and organic content. }\end{array}$ \\
\hline $\mathrm{G}$ & $\begin{array}{l}\text { Siltstone: thickness 42m-55m; light tan weathered surface, light tan } \\
\text { fresh surface; coarsens upwards gradually over the course of about } \\
\text { 6m to fine sand sized; fossiliferous; little organic material. }\end{array}$ \\
\hline $\mathrm{H}$ & $\begin{array}{l}\text { Sandstone: medium grained sandstone; thickness 38m-42m; well } \\
\text { sorted and moderately well-rounded grains; weathered surface is } \\
\text { dark brown and fresh surface is dark brown as well; shares a direct } \\
\text { contact with underlying tuffaceous siltstone and overlying siltstone. }\end{array}$ \\
\hline $\mathrm{I}$ & $\begin{array}{l}\text { Siltstone: thickness 23m-38m; both weathered and fresh surface are } \\
\text { light tan moderately indurated siltstone; crumbles into blocky } \\
\text { structure; fossiliferous; shares a direct contact with overlying } \\
\text { tuffaceous siltstone. }\end{array}$ \\
\hline $\mathrm{J}$ & $\begin{array}{l}\text { Siltstone with interbedded tuffaceous siltstone: thickness 0m-23m; } \\
\text { well indurated siltstone silt to fine sand grain size; weathered and } \\
\text { fresh surface are light tan; } 15 \% \text { pumice clasts that are mm in size; } \\
\text { shares a direct contact with overlying poorly indurated siltstone. }\end{array}$ \\
\hline
\end{tabular}

Figure 12: South Fork of the Crooked River - East Unit Descriptions

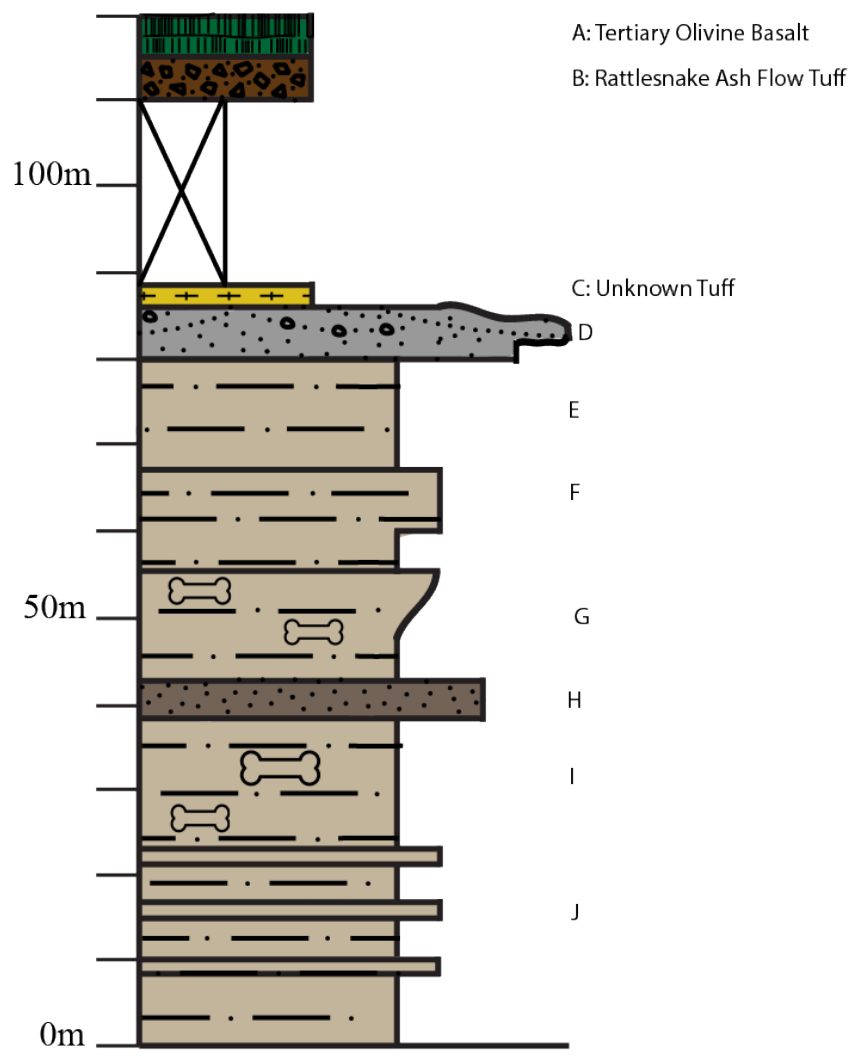


Figure 13: South Fork of the Crooked River - East Stratigraphic Column

South Fork East is a 120m thick stratigraphic section that is capped by the Tertiary

Olivine Basalt (TOB). This is the only field site that features an exposure of the TOB.

Beneath the TOB is a $5 \mathrm{~m}$ thick exposure of the Rattlesnake Ash Flow Tuff (RAFT) (B)

followed by an approximately 20m covered interval. The covered interval shares a

direct contact with the unknown tuff, shown in yellow, below (C). Directly contacting

the unknown tuff is coarse, cross-bedded sandstone that coarsens then fines upwards. It covers about $6 \mathrm{~m}$ of section (D). Beneath the sandstone is a large, $35 \mathrm{~m}$ section of siltstone that has been split into three different units based on the coarsening upwards sequences (E, F, G). The lowermost siltstone unit of the three is the most fossiliferous and it sits atop another sandstone layer that can be correlated to a coarse sandstone in Hawk Rim (H). Beneath the sandstone is more fossiliferous siltstone (I). The base of the section is $21 \mathrm{~m}$ of siltstone interbedded with tuffaceous siltstone that is not particularly fossiliferous. 


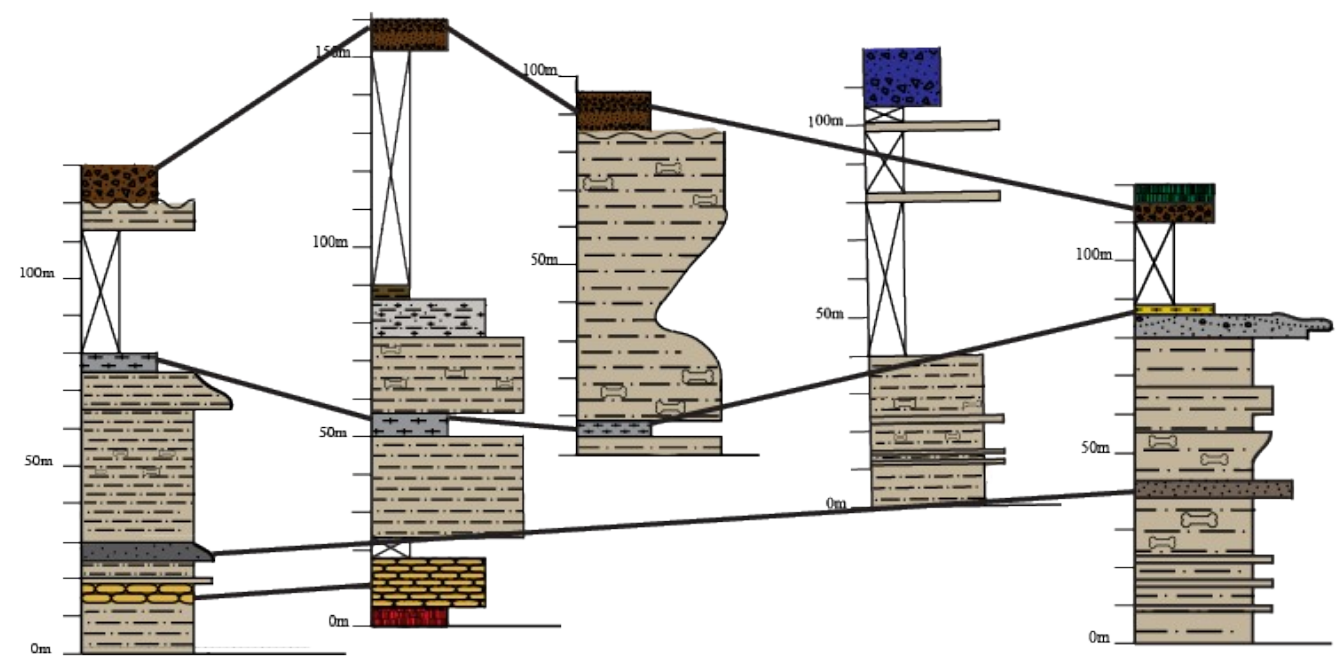

Figure 14: Fence Diagram Hypothesis One: the Unknown Tuff is the Hawk Rim Tuff

The stratigraphic columns are organized from west to east: Hawk Rim, Twin Buttes, Cave Basin, South Fork West, and South Fork East. This correlation diagram shows the unknown tuff (shown in yellow) to correlate with the Hawk Rim Tuff (HRT) which is also present in Hawk Rim, Twin Buttes, and Cave Basin. Other marker beds have been correlated: the Rattlesnake Ash Flow Tuff (RAFT) in Hawk Rim, Twin Buttes, Cave Basin, and South Fork East; the Hawk Rim Tuff (HRT) in Hawk Rim, Twin Buttes, and Cave Basin; the diatomaceous chert deposits in Hawk Rim and Twin Buttes; and finally the coarse sandstones in Hawk Rim and South Fork East. 


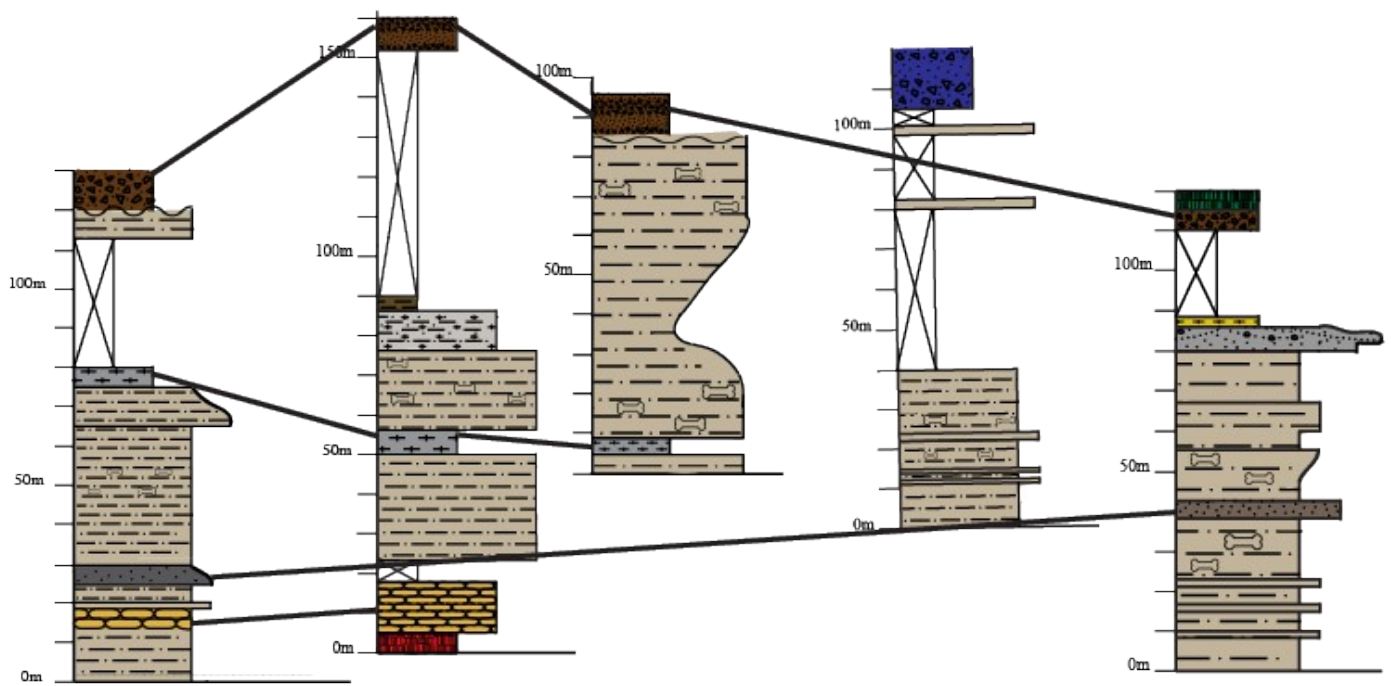

Figure 15: Fence Diagram Hypothesis Two: the Unknown Tuff is a New Tuff

The stratigraphic columns are organized from west to east: Hawk Rim, Twin Buttes, Cave Basin, South Fork West, and South Fork East. This correlation diagram shows the hypothesis that the unknown tuff (shown in yellow on South Fork East) is not the Hawk Rim Tuff (HRT). Other marker beds have been correlated: the Rattlesnake Ash Flow Tuff (RAFT) in Hawk Rim, Twin Buttes, Cave Basin, and South Fork East; the Hawk Rim Tuff (HRT) in Hawk Rim, Twin Buttes, and Cave Basin; the diatomaceous chert deposits in Hawk Rim and Twin Buttes; and finally the coarse sandstones in Hawk Rim and South Fork East. 


\section{Bibliography}

Albright, L. B., III , M. O. Woodburne, T. J. Fremd, C. C. Swisher III , B. J. MacFadden, and G. R. Scott. 2008. Revised chronostratigraphy and biostratigraphy of the John Day Formation (Turtle Cove and Kimberly Members), Oregon, with implications for updated calibration of the Arikareean North American Land Mammal Age. The Journal of Geology 16:211-237.

Bailey, Michael M. "Revisions to stratigraphic nomenclature of the Picture Gorge basalt subgroup, Columbia River basalt group." Volcanism and tectonism in the Columbia River flood-basalt province: Geological Society of America Special Paper 239 (1989): 67-84.

Barry, T. L., et al. "Eruption chronology of the Columbia River Basalt Group." The Columbia River Flood Basalt Province: Geological Society of America Special Paper 497 (2013): 45-66.

Behrensmeyer, A.K., et al. 1992. Terrestrial Ecosystems Through Time: Evolutionary Paleoecology of Terrestrial Plants and Animals. Chicago: University of Chicago Press.

Boggs Jr, Sam. Principles of sedimentology and stratigraphy. Pearson Education, 2014.

Cahoon, Emily B., et al. "Reshuffling the Columbia River Basalt chronology-Picture Gorge Basalt, the earliest-and longest-erupting formation." Geology 48.4 (2020): 348-352.

Cross, Aureal T., and Ralph E. Taggart. "Causes of Short-Term Sequential Changes in Fossil Plant Assemblages: Some Considerations Based on a Miocene Flora of the Northwest United States.” Annals of the Missouri Botanical Garden, vol. 69, no. 3, 1982, pp. 676-734. JSTOR, www.jstor.org/stable/2399088. Accessed 21 Apr. 2020.

Bestland, E. A. 1998. Stratigraphy of the Mid-Miocene Mascall Formation (Lower Part) in Its Type Area. A report prepared for the John Day Fossil Beds National Monument and Bureau of Land Management, Prineville District, Oregon, 34 pp.

Downs, T. 1956. The Mascall fauna from the Miocene of Oregon. University of California Publications in Geological Science 31(5):199-354.

Forbes, Matthew et al. "Stratigraphy, paleopedology, and geochemistry of the middle Miocene Mascall Formation (type area, Central Oregon, USA).” (2008).

Maguire, K. C, Samuels, J. X, \& Schmitz, M. D. (2018). The fauna and chronostratigraphy of the middle Miocene Mascall type area, John Day Basin, Oregon, USA. PaleoBios, 35. 
McLaughlin, Win N.F., et al. “A New Late Hemingfordian Vertebrate Fauna from Hawk Rim, Oregon, with Implications for Biostratigraphy and Geochronology.” Journal of Vertebrate Paleontology, 19 Mar. 2016, doi:10.1080/02724634.2016.1201095.

McLaughlin, W., \& Hopkins, Samantha. (2012). Hawk Rim: A Geologic and Paleontological Description of a New Barstovian Locality in Central Oregon.

Retallack, G. J. 2004. Late Miocene climate and life on land in Oregon within a context of Neogene global change. Palaeogeography, Palaeoclimatology, Palaeoecology 214:97-123

Retallack, Gregory J. "Late Oligocene bunch grassland and early Miocene sod grassland paleosols from central Oregon, USA." Palaeogeography, Palaeoclimatology, Palaeoecology 207.3-4 (2004): 203-237.

Streck, M.J., Grunder, A.L. Crystallization and welding variations in a widespread ignimbrite sheet; the Rattlesnake Tuff, eastern Oregon, USA. Bull Volcanol 57, 151-169 (1995). 